Cereal Research Communications 36(1), pp. 157-166 (2008)

DOI: $10.1556 / C R C .36 .2008 .1 .16$

\title{
Nitrogen and Phosphorus Accumulation and Remobilization of Durum Wheat as Affected by Soil Gravel Content
}

\author{
A. MASONI ${ }^{1}$, L. ERCOLI $^{2} *$, M. MARIOTTI ${ }^{1}$ and S. PAMPANA ${ }^{1}$ \\ ${ }^{1}$ Dipartimento di Agronomia e Gestione dell'Agroecosistema, via S. Michele degli Scalzi 2, \\ 56124, Pisa, Italy \\ ${ }^{2}$ Scuola Superiore Sant'Anna di Studi Universitari e di Perfezionamento, \\ Piazza Martiri della Libertà 33, 56127, Pisa, Italy
}

(Received 26 January 2007; accepted 26 March 2007)

\begin{abstract}
Soil gravel content affects many soil physical properties, as well as crop yield. Little is known regarding the influence of soil gravel content on growth and nutrient uptake of durum wheat (Triticum durum Desf.). The accumulation of nitrogen and phosphorous during the vegetative and reproductive periods and the contribution of pre-anthesis assimilates to grain $\mathrm{N}$ and $\mathrm{P}$ content have been evaluated in two durum wheat varieties grown on soils with $0,10,20$ and $30 \%$ gravel content. The two varieties showed similar behaviour and the increase of soil gravel decreased plant biomass during the entire biological cycle. Nitrogen and P concentration of all plant parts was not affected by soil gravel content, while $\mathrm{N}$ and $\mathrm{P}$ content was greatly reduced, owing to the effect on dry matter yield. Post-anthesis accumulation and remobilization of $\mathrm{N}$ and $\mathrm{P}$ were greatly reduced: the decrease from gravel-free soil to $30 \%$ gravel content was about $41 \mathrm{~kg} \mathrm{Nha}^{-1}$ and $4 \mathrm{~kg} \mathrm{Pha}^{-1}$ for the former and $14 \mathrm{~kg} \mathrm{~N} \mathrm{ha}^{-1}$ and $2 \mathrm{~kg} \mathrm{P} \mathrm{ha}^{-1}$ for the latter. The differences in growth rate were attributed to differences in development of the root system due to the restricted soil volume.
\end{abstract}

Keywords: accumulation, durum wheat, gravel content, nitrogen, phosphorus, remobilization

\section{Introduction}

Soils containing rock fragments are widespread, particularly in the Mediterranean area, where they often occupy more than $60 \%$ of the land surface (Poesen 1990). Information on the behaviour of these soils is especially needed because of their potential limitations for land use and to improve models aiming at predicting

\footnotetext{
* Corresponding author; E-mail: ercoli@sssup.it
} 
the effects of climatic and land use changes on the response of these soils (Poesen and Lavee 1994).

Plough layers containing rock fragments have a higher macro-porosity, saturated hydraulic conductivity and daily maximum temperature than stone-free soils (Ravina and Magier 1984; Danalatos et al. 1995; van Wesemael et al. 1995). Little research has addressed the effects of rock fragment content of soil on crop productivity. With increasing rock fragment content, decaying organic matter, nutrients and rain water are concentrated in a decreasing mass of fine earth, thus root ability to supply the shoot with adequate water and nutrients is reduced (Kosmas et al. 1994; Poesen and Lavee 1994). However, pot studies showed that very small amounts of soil could support excellent plant growth, if the supply of water, nutrients and other resources is not limiting (Korner et al. 1989).

In winter cereals, the supply of assimilates to grain originates from current assimilation transferred directly to kernels and from the remobilization of assimilates stored temporarily in vegetative plant parts before anthesis (Gebbing et al. 1999). After anthesis, plants continue both growth and $\mathrm{N}$-assimilation, and significant quantities of $\mathrm{N}$ can be assimilated during grain filling (Austin et al. 1977; Cox et al. 1985). Remobilization of soluble carbohydrates from vegetative plant parts also contributes to grain dry weight, although the contribution from remobilization is usually small compared to current photosynthesis. The remobilization of previous assimilated $\mathrm{N}$ accounted for 51 to $91 \%$ of grain $\mathrm{N}$ yield, and most of this variability can be attributed to differences in crop management, soil type effects, climate and genotypes (Cox et al. 1985; Papakosta and Gagianas 1991; Ehdaie and Waines 2001). High N remobilization may result indirectly from limits to nitrogen uptake during the grain-filling period, forcing the plant to make greater use of its stored nitrogen (Barbottin et al. 2005).

Phosphorus uptake and remobilization during grain filling in wheat has received much less attention. The amount of grain $\mathrm{P}$ derived from remobilization ranged from 11 to $100 \%$, according to $\mathrm{P}$ availability, climate and genotypes (Batten et al. 1986; Papakosta 1994).

The objectives of this research were to study the effect of the content of gravel in soil on the accumulation of nitrogen and phosphorus during the vegetative and reproductive periods and the contribution of pre-anthesis assimilates to grain yield of a modern and an old durum wheat variety, differing in growth patterns. 


\section{Materials and Methods}

Full description of the site and detailed procedures in the field experiments have been reported in a previous paper (Ercoli et al. 2006). Briefly, durum wheat varieties Cirillo and Creso were grown in open-air lysimeters on soils with 0,10 , 20 and $30 \%$ gravel content (v/v). Cultural practices were those conventionally applied in the region. Fertilization consisted of $120 \mathrm{~kg} \mathrm{ha}^{-1} \mathrm{~N}$ as urea, $100 \mathrm{~kg} \mathrm{ha}^{-1}$ $\mathrm{P}_{2} \mathrm{O}_{5}$ as triple super phosphate and $100 \mathrm{~kg} \mathrm{ha}^{-1} \mathrm{~K}_{2} \mathrm{O}$ as potassium sulphate. Crops were irrigated when necessary to avoid water stress. As a whole, irrigation was not applied before anthesis in both years and between anthesis and maturity irrigation was applied once in 2001-2002 and four times in 2002-2003. Water was distributed utilizing a microirrigation system until field capacity was reached.

In both years after each major rainfall event, leachates from each lysimeter were collected in a 20-L PVC tank during all research period. Leachates volume was measured and their $\mathrm{N}-\mathrm{NO}_{3}$ concentration was determined with an Orion ion analyzer model 502A. The flow-weighted $\mathrm{N}^{-\mathrm{NO}_{3}}$ concentration for the whole leaching period was calculated by summing up $\mathrm{N}-\mathrm{NO}_{3}$ mass collected in the period divided by the total leachate volume.

Measurements of crop growth were done at anthesis, stage 60 of the scale of Zadoks et al. (1974) on 22 April 2002 and 21 April 2003, and at physiological maturity, stage 90, on 10 June 2002 and 11 June 2003. All plants in each lysimeter were cut at ground level and were separated into leaves, culms and spikes at anthesis and into leaves, culms, chaff and grain at maturity. Roots were separated from the soil by washing with water until the roots were totally clean. Plant samples were analyzed for nitrogen (microKjeldahl) and phosphorus (ammonium-molybdophosphoric blue color method) concentration. Nitrogen and phosphorus harvest index was also calculated as: (grain $\mathrm{N}$ or $\mathrm{P}$ content / shoot $\mathrm{N}$ or $\mathrm{P}$ content) $\times 100$.

The following parameters were calculated:

1. post-anthesis $\mathrm{N}$ and $\mathrm{P}$ accumulation, as the difference between $\mathrm{N}$ or $\mathrm{P}$ content of the whole plant at anthesis and at physiological maturity;

2. nitrogen and $\mathrm{P}$ remobilization $=$ content of $\mathrm{N}$ or $\mathrm{P}$ of the whole plant at anthesis - content of $\mathrm{N}$ or $\mathrm{P}$ of roots, leaves, culms and chaff at maturity;

3. nitrogen and $\mathrm{P}$ remobilization efficiency $=($ remobilization of $\mathrm{N}$ or $\mathrm{P} /$ content of $\mathrm{N}$ or $\mathrm{P}$ of the whole plant at anthesis $) \times 100$;

4. contribution of remobilization to grain content $=($ remobilization of $\mathrm{N}$ or $\mathrm{P} /$ grain $\mathrm{N}$ or $\mathrm{P}$ content at maturity) $\times 100$.

For the estimate of $\mathrm{N}$ and $\mathrm{P}$ remobilization it was assumed that all of the $\mathrm{N}$ and $\mathrm{P}$ lost from vegetative plant parts was remobilized to the developing grain, 
since losses of dry matter due to plant respiration and losses of $\mathrm{N}$ due to volatilization during grain filling were not determined.

Data were statistically treated by ANOVA, in order to test the main effects of year, soil gravel content and variety and their interactions. Separate statistical analyses were conducted for $\mathrm{N}$ and $\mathrm{P}$ accumulation and remobilization for each harvest. Because the main effect of year and its interactions were not significant, a successive analysis of variance was carried out using years as replications. Duncan's multiple range test was used to separate the means when the ANOVA F-test indicated a significant effect of the treatment (Steel and Torrie 1980).

\section{Results}

For all characters, the variety $\times$ soil gravel content interaction was not significant; therefore only variety and soil gravel content mean effects are discussed in the paper.

At both stages, $\mathrm{N}$ concentration in all plant parts was not significantly different between varieties and soil gravel contents. Averaged over all treatments, $\mathrm{N}$ concentration decreased from anthesis to maturity in leaves, culms and spikes, while it slightly increased in roots (results not shown).

From anthesis to maturity, $\mathrm{N}$ content, at any given treatment, decreased in leaves, culms and roots and increased in spikes and grain, thus suggesting an export of $\mathrm{N}$ from vegetative plant parts to spikes (Tables 1 and 2). At both stages, varieties differed in their ability to accumulate nitrogen in vegetative organs: $\mathrm{N}$ content in leaves and culms of Creso was $7.2 \mathrm{~kg} \mathrm{ha}^{-1}$ higher than Cirillo at anthesis and $8 \mathrm{~kg} \mathrm{ha}^{-1}$ higher at maturity (Table 1).

Table 1. Nitrogen content of leaves, culms, spikes, grain, roots and whole plant at anthesis and at physiological maturity. Variety mean values. Means followed by the same letter, within the same treatment and column, are not significantly different at $\mathrm{P} \leq 0.05$

\begin{tabular}{|c|c|c|c|c|c|c|}
\hline \multirow[t]{3}{*}{ Variety } & Leaves & Culms & Spikes & Grain & Roots & Whole plant \\
\hline & \multicolumn{6}{|c|}{$\mathrm{kg} \mathrm{ha}^{-1}$} \\
\hline & \multicolumn{6}{|c|}{ Anthesis } \\
\hline Cirillo & $46.2 \mathrm{a}$ & $33.6 \mathrm{a}$ & $21.5 \mathrm{a}$ & - & $22.0 \mathrm{a}$ & $123.3 \mathrm{a}$ \\
\hline \multirow[t]{2}{*}{ Creso } & $50.2 \mathrm{~b}$ & $36.8 \mathrm{~b}$ & $21.7 \mathrm{a}$ & - & $21.8 \mathrm{a}$ & $130.5 \mathrm{a}$ \\
\hline & \multicolumn{6}{|c|}{ Maturity } \\
\hline Cirillo & $9.2 \mathrm{a}$ & $17.3 \mathrm{a}$ & $102.3 \mathrm{a}$ & $83.2 \mathrm{a}$ & $15.0 \mathrm{a}$ & $143.7 \mathrm{a}$ \\
\hline Creso & $13.4 \mathrm{~b}$ & $21.1 \mathrm{~b}$ & $96.3 \mathrm{a}$ & $80.5 \mathrm{a}$ & $15.0 \mathrm{a}$ & $145.8 \mathrm{a}$ \\
\hline
\end{tabular}

The effect of soil gravel on $\mathrm{N}$ content, averaged over varieties, was statistically significant for all plant parts of wheat, owing to the effect of gravel on dry 
matter yield (Table 2). At both stages, soil gravel levels reduced $\mathrm{N}$ content of all plant parts. In the whole plant the reduction from the control to the highest soil gravel content was by $30 \%$ at anthesis and by $45 \%$ at maturity, corresponding to a reduction of, respectively, 45 and $85 \mathrm{~kg} \mathrm{~N} \mathrm{ha}^{-1}$.

Table 2. Influence of soil gravel content on $\mathrm{N}$ and $\mathrm{P}$ content of leaves, culms, spikes and roots at anthesis and at physiological maturity. Means followed by the same letter, within the same treatment and column, are not significantly different at $\mathrm{P} \leq 0.05$

\begin{tabular}{|c|c|c|c|c|c|c|c|c|}
\hline \multirow{3}{*}{$\begin{array}{l}\text { Soil gravel } \\
\text { content } \\
\% \mathrm{v} / \mathrm{v}\end{array}$} & \multicolumn{4}{|c|}{ Anthesis } & \multicolumn{4}{|c|}{ Maturity } \\
\hline & Leaves & Culms & Spikes & Roots & Leaves & Culms & Spikes & Roots \\
\hline & \multicolumn{8}{|c|}{$\mathrm{kg} \mathrm{ha}^{-1}$} \\
\hline & \multicolumn{8}{|c|}{ Nitrogen } \\
\hline 0 & $54.4 \mathrm{a}$ & $39.2 \mathrm{a}$ & $29.7 \mathrm{a}$ & $26.8 \mathrm{a}$ & $12.3 \mathrm{a}$ & $20.4 \mathrm{ab}$ & $140.9 \mathrm{a}$ & $17.9 \mathrm{a}$ \\
\hline 10 & $52.2 \mathrm{a}$ & $37.4 \mathrm{a}$ & $23.9 \mathrm{~b}$ & $23.7 \mathrm{a}$ & $13.7 \mathrm{a}$ & $24.1 \mathrm{a}$ & $104.8 \mathrm{~b}$ & $16.3 \mathrm{a}$ \\
\hline 20 & $45.9 b$ & $33.1 b$ & $17.4 \mathrm{c}$ & $18.6 \mathrm{~b}$ & $10.6 \mathrm{ab}$ & $17.7 \mathrm{bc}$ & $77.4 \mathrm{c}$ & $12.5 b$ \\
\hline \multirow[t]{2}{*}{30} & $40.8 \mathrm{c}$ & $30.8 \mathrm{~b}$ & $15.5 \mathrm{c}$ & $18.4 \mathrm{ab}$ & $8.3 \mathrm{~b}$ & $15.1 \mathrm{c}$ & $71.0 \mathrm{c}$ & $11.9 \mathrm{~b}$ \\
\hline & \multicolumn{8}{|c|}{ Phosphorus } \\
\hline 0 & $4.1 \mathrm{a}$ & $7.1 \mathrm{a}$ & $6.3 \mathrm{a}$ & $2.9 \mathrm{a}$ & $0.9 \mathrm{a}$ & $2.2 \mathrm{ab}$ & $21.5 \mathrm{a}$ & $1.8 \mathrm{a}$ \\
\hline 10 & $4.2 \mathrm{a}$ & $6.6 \mathrm{a}$ & $4.6 \mathrm{a}$ & $2.8 \mathrm{a}$ & $1.1 \mathrm{a}$ & $2.8 \mathrm{~b}$ & $18.7 \mathrm{~b}$ & $1.4 \mathrm{a}$ \\
\hline 20 & $3.9 \mathrm{a}$ & $6.9 \mathrm{a}$ & $3.4 \mathrm{~b}$ & $2.2 \mathrm{a}$ & $1.0 \mathrm{a}$ & $2.0 \mathrm{ab}$ & $16.7 b c$ & $1.2 \mathrm{a}$ \\
\hline 30 & $3.9 \mathrm{a}$ & $6.3 \mathrm{a}$ & $3.2 \mathrm{~b}$ & $2.3 \mathrm{a}$ & $0.8 \mathrm{a}$ & $1.3 \mathrm{a}$ & $14.7 \mathrm{c}$ & $1.1 \mathrm{a}$ \\
\hline
\end{tabular}

Nitrogen harvest index did not differ between varieties and was not modified by soil gravel content. On average, NHI was $56 \%$.

Durum wheat varieties differed for post-anthesis $\mathrm{N}$ accumulation and remobilization. Post-anthesis $\mathrm{N}$ accumulation of Cirillo was $5.1 \mathrm{~kg} \mathrm{ha}^{-1}$ higher than that of Creso and $\mathrm{N}$ remobilization was $2.4 \mathrm{~kg} \mathrm{ha}^{-1}$ lower (results not shown). Averaged over soil type, the ratio between $\mathrm{N}$ remobilization and $\mathrm{N}$ accumulation was 3.1 for Cirillo and 4.3 for Creso and the contribution of remobilized $\mathrm{N}$ to grain-N content was $75 \%$ and $81 \%$, respectively.

Post-anthesis $\mathrm{N}$ accumulation and remobilization were greatly affected by soil gravel content (Table 3). Post-anthesis $\mathrm{N}$ accumulation linearly decreased with the increase of soil gravel content from $41.5 \mathrm{~kg} \mathrm{~N} \mathrm{ha}^{-1}$ of gravel-free soil to less than $1 \mathrm{~kg} \mathrm{ha}^{-1}$ of $30 \%$ soil gravel content. As a consequence, the $\mathrm{N}$ taken up during grain filling accounted for $22 \%$ of the total $\mathrm{N}$ uptake at maturity in gravel-free soil, for $14 \%$ with $10 \%$ gravel content and for only 3 and $1 \%$ with the two highest gravel contents. Also $\mathrm{N}$ remobilization during grain filling linearly decreased with the increase of soil gravel content from $72 \mathrm{~kg} \mathrm{~N} \mathrm{ha}^{-1}$ of gravel-free soil to $58 \mathrm{~kg} \mathrm{ha}^{-1}$ of $30 \%$ soil gravel content.

Post-anthesis $\mathrm{N}$ remobilization was higher than $\mathrm{N}$ accumulation at all soil gravel contents but the ratio between the former and the latter dramatically in- 
creased from 1.7 of gravel-free soil to 73 with the highest soil gravel content. As a consequence, nitrogen remobilization become crucial for the $\mathrm{N}$ content of durum wheat at high soil gravel content, representing the only source of $\mathrm{N}$ for the grain when gravel content was 30\%. Remobilization efficiency of $\mathrm{N}$ from vegetative to reproductive organs of durum wheat did not vary between varieties and was only slightly increased by gravel content (Table 3).

Varieties did not differ for leachate volume and $\mathrm{N}-\mathrm{NO}_{3}$ concentration and loss, while soil gravel content greatly modified $\mathrm{N}$ leaching. In Table 4 the total leachate volumes, $\mathrm{N}-\mathrm{NO}_{3}$ leaching losses and the flow-weighted $\mathrm{N}-\mathrm{NO}_{3}$ concentration for the whole leaching period are reported averaged over the two years and varieties. Leachates were collected from December to April in both years, thereafter both low rain and high crop Effective Evapotranspiration prevented drainage. Leachate volume recorded in the whole leaching period increased with the increase of soil gravel content. Compared to control, 20 and $30 \%$ soil gravel contents increased drainage by over $50 \%$ (Table 4). The flow-weighted $\mathrm{N}^{-\mathrm{NO}_{3}}$ concentration for the whole leaching period decreased with the increase of soil gravel content by about $58 \%$ from the control to the two higher soil gravel contents. Following the pattern of both leachate volume and $\mathrm{N}-\mathrm{NO}_{3}$ concentration, the mass of $\mathrm{N}-\mathrm{NO}_{3}$ in the whole leaching period decreased with the increase of soil gravel content. Values for the whole leaching period at 20 and 30\% soil gravel contents were $43 \%$ lower than the control. The lower $\mathrm{N}$ leaching with the two highest gravel contents was probably the result of the reduced potential for mineralization of $\mathrm{N}$ from the soil organic matter in the decreased mass of fine earth.

Table 3. Influence of soil gravel content on post-anthesis accumulation, remobilization and remobilization efficiency of $\mathrm{N}$ and $\mathrm{P}$, and contribution of $\mathrm{N}$ and $\mathrm{P}$ remobilization to grain $\mathrm{N}$ and $\mathrm{P}$ content. Means followed by the same letter, within the same treatment and column, are not significantly different at $\mathrm{P} \leq 0.05$

\begin{tabular}{|c|c|c|c|c|}
\hline $\begin{array}{l}\text { Soil gravel } \\
\text { content }\end{array}$ & $\begin{array}{l}\text { Post-anthesis } \\
\text { accumulation }\end{array}$ & Remobilization & $\begin{array}{c}\text { Remobilization } \\
\text { efficiency }\end{array}$ & $\begin{array}{l}\text { Contribution of } \\
\text { remobilization to grain }\end{array}$ \\
\hline \multirow[t]{2}{*}{$\% \mathrm{v} / \mathrm{v}$} & \multicolumn{2}{|c|}{$\mathrm{kg} \mathrm{ha}^{-1}$} & \multicolumn{2}{|r|}{$\%$} \\
\hline & \multicolumn{4}{|c|}{ Nitrogen } \\
\hline 0 & $41.5 \mathrm{a}$ & $71.6 \mathrm{a}$ & $47.7 \mathrm{a}$ & $63.3 \mathrm{a}$ \\
\hline 10 & $21.7 \mathrm{~b}$ & $65.3 b$ & $47.6 \mathrm{a}$ & $75.1 \mathrm{~b}$ \\
\hline 20 & $3.2 \mathrm{c}$ & $62.1 \mathrm{bc}$ & $54.0 \mathrm{~b}$ & $95.2 \mathrm{c}$ \\
\hline \multirow[t]{2}{*}{30} & $0.8 \mathrm{c}$ & $57.7 \mathrm{c}$ & $54.6 \mathrm{~b}$ & $98.6 \mathrm{~d}$ \\
\hline & \multicolumn{4}{|c|}{ Phosphorus } \\
\hline 0 & $6.0 \mathrm{a}$ & $13.1 \mathrm{a}$ & $64.1 \mathrm{a}$ & $68.6 \mathrm{a}$ \\
\hline 10 & $5.8 \mathrm{a}$ & $10.7 \mathrm{ab}$ & $58.6 \mathrm{a}$ & $64.8 \mathrm{a}$ \\
\hline 20 & $4.5 \mathrm{a}$ & $10.8 \mathrm{c}$ & $65.3 \mathrm{a}$ & $70.7 \mathrm{a}$ \\
\hline 30 & $2.1 \mathrm{~b}$ & $11.2 \mathrm{bc}$ & $71.4 \mathrm{~b}$ & $84.3 b$ \\
\hline
\end{tabular}


Table 4. Influence of soil gravel content on leachates volumes, $\mathrm{N}$ concentration and $\mathrm{N}$ mass in leachates during the whole leaching period. Means followed by the same letter, within the same column, are not significantly different at $\mathrm{P} \leq 0.05$

\begin{tabular}{lccc}
\hline $\begin{array}{l}\text { Soil gravel } \\
\text { content }\end{array}$ & $\begin{array}{c}\text { Leachates } \\
\text { volume }\end{array}$ & $\begin{array}{c}\text { N concentration } \\
\text { in leachates }\end{array}$ & $\begin{array}{c}\text { N mass } \\
\text { in leachates }\end{array}$ \\
\hline$\% \mathrm{v} / \mathrm{v}$ & $\mathrm{L} \mathrm{m}^{-2}$ & $\mathrm{mg} \mathrm{L}^{-1}$ & $\mathrm{~g} \mathrm{~m}^{-2}$ \\
\hline 0 & $63.5 \mathrm{a}$ & $68.3 \mathrm{a}$ & $43.3 \mathrm{a}$ \\
10 & $72.3 \mathrm{~b}$ & $46.7 \mathrm{~b}$ & $33.7 \mathrm{~b}$ \\
20 & $97.0 \mathrm{c}$ & $28.0 \mathrm{c}$ & $27.2 \mathrm{c}$ \\
30 & $100.8 \mathrm{c}$ & $28.0 \mathrm{c}$ & $28.2 \mathrm{c}$ \\
\hline
\end{tabular}

Phosphorus concentration of all plant parts did not vary between varieties and soil gravel contents. Phosphorus content of all plant parts did not vary between varieties and it was slightly affected by soil gravel content (Table 2). At anthesis, only spike $\mathrm{P}$ content was significantly reduced by gravel while, at maturity, culm, spike and grain $\mathrm{P}$ contents were all reduced. Thus, at the highest gravel content, whole plant $\mathrm{P}$ content was $23 \%$ lower at anthesis and $32 \%$ lower at maturity than in control.

Phosphorus harvest index did not differ between varieties and was not modified by soil gravel content. On average, PHI was $77 \%$.

Durum wheat varieties did not differ for post-anthesis $\mathrm{P}$ accumulation and remobilization. Post-anthesis $\mathrm{P}$ accumulation and remobilization were decreased by soil gravel content. Accumulation decreased from $6 \mathrm{~kg} \mathrm{P} \mathrm{ha}^{-1}$ of gravel-free soil to $2 \mathrm{~kg} \mathrm{ha}^{-1}$ of $30 \%$ soil gravel content. As a consequence, the $\mathrm{P}$ taken up during grain filling accounted for $23 \%$ of the total $\mathrm{P}$ uptake at maturity in the gravel-free soil and for $12 \%$ with $30 \%$ gravel content. Phosphorus remobilization during grain filling decreased by $14 \%$ from gravel-free soil to the highest soil gravel content (Table 3).

Post-anthesis $\mathrm{P}$ remobilization was higher than $\mathrm{P}$ accumulation at all soil gravel contents, and the ratio remobilization/accumulation increased with the increase of soil gravel level from 2.2 of gravel-free soil to 5.4 of the highest soil gravel content. As a consequence, $\mathrm{P}$ remobilization accounted for $69 \%$ of grain $\mathrm{P}$ content in gravel-free soil and for $84 \%$ when gravel content was $30 \%$. Phosphorous remobilization efficiency from vegetative to reproductive organs of durum wheat did not vary between varieties and was increased only by the highest soil gravel content (Table 3). 


\section{Discussion}

This is the second of two papers aiming to study the effect of soil gravel content on the relative contribution of dry matter, $\mathrm{N}$ and $\mathrm{P}$ accumulation and remobilization during grain filling of durum wheat. In the first paper, results demonstrated that the increase of gravel decreased plant growth, thereby reducing either the source for grain growth, i.e. the photosynthetizing biomass and the uptake ability of roots, or the sink size, represented by the number of spikes per unit area and of kernels per spike. Post-anthesis dry matter accumulation was not greatly affected by gravel content, while dry matter remobilization was markedly reduced (Ercoli et al. 2006).

In this research, $\mathrm{N}$ and $\mathrm{P}$ contents of plants were greatly reduced by the increase of soil gravel content, owing to the effect on dry matter yield. During grain filling, both $\mathrm{N}$ and $\mathrm{P}$ uptake and remobilization were reduced by gravel, but uptake was more sensitive than remobilization. At the highest gravel level, $\mathrm{N}$ and $\mathrm{P}$ assimilation were close to 0 and all $\mathrm{N}$ and $\mathrm{P}$ content of grain derived from remobilization. The amount of remobilized $\mathrm{N}$ and $\mathrm{P}$ depends on the amount of $\mathrm{N}$ and $\mathrm{P}$ available for remobilization and on $\mathrm{N}$ and $\mathrm{P}$ remobilization efficiency. Cox et al. (1986) and Barbottin et al. (2005) showed that $\mathrm{N}$ remobilization efficiency increased as a result of environmental conditions limiting nitrogen uptake during grain-filling. In our research, $\mathrm{N}$ and $\mathrm{P}$ remobilization efficiency were not appreciably modified by soil gravel content, so the variation of remobilization was due to the amount of $\mathrm{N}$ and $\mathrm{P}$ available at anthesis.

The varieties Cirillo and Creso showed a similar behaviour, and differences in soil gravel content induced similar changes in $\mathrm{N}$ and $\mathrm{P}$ accumulation and remobilization. However, although no consistent differences in grain yield and grain $\mathrm{N}$ content occurred between Cirillo and Creso, the higher biomass and $\mathrm{N}$ content of Creso at anthesis was associated with a higher remobilization and a lower accumulation of dry matter and $\mathrm{N}$ during grain filling. Thus, grain yield and $\mathrm{N}$ content of Creso relied largely on remobilization of reserves rather than on photosynthesis and mineral uptake during grain filling.

The increase of soil gravel content increased drainage water and decreased $\mathrm{N}$ concentration in leachates and the total leached $\mathrm{N}$, indicating an higher amount of nitrogen as nitrate in stone free soil, owing to the higher fine earth mass and the higher mineralizable organic matter amount. The difference of leached $\mathrm{N}$ from the highest gravel content to the gravel-free soil was about $15 \mathrm{~kg} \mathrm{ha}^{-1}$.

In the previous paper we have hypothized that soil gravel reduced plant growth mainly reducing root size and functionality. The mechanisms involved in the response of plants to root restriction are not clear. Carmi and Heuer (1981) showed that dwarfishness of bean plants grown in small pots was not caused by 
water or nutrient deficiency and Masoni et al. (1997) suggested that maize plants growing in reduced root zone volumes were not able to uptake nutrients, even though high levels of nutrients were supplied, owing to excessive root density in soil pores which reduced soil aeration and root respiration. In our research, severe mineral deficiency was not likely to occur, since $\mathrm{N}$ and $\mathrm{P}$ fertilization rate per unit area was the same at all gravel treatments. Thus, if the rate per unit fine earth was already optimal in stone free soil it was even higher with stoney soils. However, the reduced amount of fine earth in gravelly soils produced a reduced release of $\mathrm{N}$ by mineralization of organic matter. The lack of mineral deficiency is confirmed by $\mathrm{N}$ and $\mathrm{P}$ concentrations of all plant parts that did not vary between varieties and were not affected by soil gravel content. Also water deficiency, which may be expected in gravelly soils, in our experiment was not likely to occur. Indeed, during the tillering and jointing stages rainfall was high, and even exceeded soil waterholding capacity. Moreover, during grain filling, irrigations were performed to avoid plant water stress. According to Abbad et al. (2004) and Plaut et al. (2004) water deficit greatly reduced the relative contribution of vegetative organs to grain dry weight. The fact that the contribution of remobilization to grain yield was not greatly affected by soil gravel provides some supporting evidence for the hypothesis of the lack of water stress.

In conclusion, it is assumed that soil gravel content, restricting root growth without causing severe stress of water and nutrients, affects wheat grain yield mainly reducing post-anthesis accumulation of nutrients.

\section{References}

Abbad, H., El Jaafari, S., Bort, J., Araus, J.L. 2004. Comparison of flag leaf and ear photosynthesis with biomass and grain yield of durum wheat under various water conditions and genotypes. Agronomie 24:19-28.

Austin, R.B., Edrich, J.A., Ford, M.A., Blackwell, R.D. 1977. The fate of dry matter, carbohydrates and ${ }^{14} \mathrm{C}$ lost from the leaves and stems of wheat during grain filling. Ann. Bot. 41:1309-1321.

Barbottin, A., Lecomte, C., Bouchard, C., Jeuffroy, M. 2005. Nitrogen remobilization during grain filling in wheat: genotypic and environmental effects. Crop Sci. 45:1141-1150.

Batten, G.D., Wardlaw, I.F., Aston, M.J. 1986. Growth and the distribution of phosphorus in wheat developed under various phosphorus and temperature regimes. Aust. J. Agric. Res. 37:459-469.

Carmi, A., Heuer, B. 1981. The role of roots in control of bean shoot growth. Ann. Bot. 48:519-527.

Cox, M.C., Qualset, C.O., Rains, D.W. 1985. Genetic variation for nitrogen assimilation and translocation in wheat. II. Nitrogen assimilation in relation to grain yield and protein. Crop Sci. 25:435-440

Cox, M.C., Qualset, C.O., Rains, D.W. 1986. Genetic variation for nitrogen assimilation and translocation in wheat. III. Nitrogen translocation in relation to grain yield and protein. Crop Sci. 26:737-740. 
Danalatos, N.G., Kosmas, C.S., Moustakas, N.C., Yassoglou, N. 1995. Rock fragments. II Their impact on soil physical properties and biomass production under Mediterranean conditions. Soil Use Manage. 11:121-126.

Ehdaie, B., Waines, J.G. 2001. Sowing date and nitrogen rate effects on dry matter and nitrogen partitioning in bread and durum wheat. Field Crops Res. 73:47-61.

Ercoli, L., Masoni, A., Mariotti, M., Arduini, I. 2006. Dry matter accumulation and remobilization of durum wheat as affected by soil gravel content. Cereal Res. Commun. 34:1299-1306.

Gebbing, T., Schnyder, H., Kühbauch, W. 1999. The utilization of pre-anthesis reserves in grain filling of wheat. Assessment by steady-state ${ }^{13} \mathrm{CO}_{2} /{ }^{12} \mathrm{CO}_{2}$ labelling. Plant, Cell Environ. 22: 851-858.

Korner, C., Pelaez Menendez-Riedl, S., John, P.C.L. 1989. Why are bonsai plants small? A consideration of cell size. Aust. J. Plant Physiol. 16:443-448.

Kosmas, C., Moustakas, N., Danalatos, N.G., Yassoglou, N. 1994. The effect of rock fragments on wheat biomass production under highly variable moisture conditions in Mediterranean environments. Catena 23:191-198.

Masoni, A., Mariotti, M., Ercoli, L. 1997. Maize growth and nutrient uptake as affected by root zone volume. Italian J. Agron. 2:95-102.

Papakosta, D.K. 1994. Phosphorus accumulation and translocation in wheat as affected by cultivar and nitrogen fertilization. J. Agron. Crop Sci. 173:260-270.

Papakosta, D.K., Gagianas, A.A. 1991. Nitrogen and dry matter accumulation, remobilization, and losses for Mediterranean wheat during grain filling. Agron. J. 83:864-870.

Plaut, Z., Butow, B.J., Blumenthal, C.S., Wrigley, C.W. 2004. Transport of dry matter into developing wheat kernels and its contribution to grain yield under post-anthesis water deficit and elevated temperature. Field Crops Res. 86:185-198.

Poesen, J. 1990. Erosion process research in relation to soil erodibility and some implications for improving soil quality. In: Albaladejo, J., Stocking, M.A., Diaz, E. (eds), Soil Degradation and Rehabilitation in Mediterranean Environmental Conditions. CSIC, Murcia, pp. 159-170.

Poesen, J., Lavee, H. 1994. Rock fragments in top soils: significance and processes. Catena 23:1-28.

Ravina, I., Magier, J. 1984. Hydraulic conductivity and water retention of clay soils containing rock fragments. Soil Sci. Soc. Am. J. 48:736-740.

Steel, R.G.D., Torrie, J.H. 1980. Principles and Procedures of Statistics. McGraw-Hill, New York. van Wesemael, B., Poesen, J., de Figueiredo, T. 1995. Effects of rock fragments on physical degradation of cultivated soils by rainfall. Soil Tillage Res. 33:229-250.

Zadoks, J.C., Chang, T.T., Konzak, C.F. 1974. A decimal code for the growth stages of cereals. Weed Res. 14:415-421.

Cereal Research Communications 36, 2008 